JPSCR: Journal of Pharmaceutical Science and Clinical Research, 2020, 01, 01-11

DOI: $10.20961 /$ jpscr.v5i1.32200

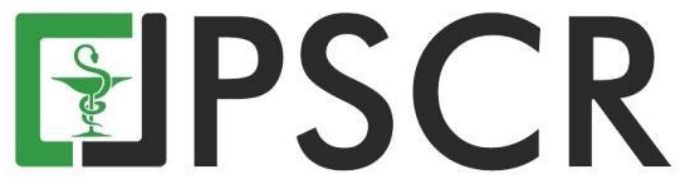

\title{
Skrining Fitokimia dan Uji Aktivitas Antibakteri Ekstrak dan Fraksi Tanaman Senggugu (Rotheca serrata (L.) Steane \& Mabb.) terhadap Pseudomonas aeruginosa
}

\author{
Ifan A. Maulana, Bawon Triatmoko dan Ari S. Nugraha* \\ Drug Utilization and Discovery Research Group, Fakultas Farmasi, Universitas Jember, Jl. Klaimantan I/2, \\ Jember, Indonesia 68121 \\ *email korespondensi : arisatia@unej.ac.id
}

\begin{abstract}
Abstrak: Irasionalitas terapi antibiotik yang tidak terkontrol dilaporkan menyebabkan bakteri resisten antibiotik, sehingga memicu penemuan agen antibakteri baru. Eksplorasi keanekaragaman tanaman obat Indonesia masih menjanjikan sebagai agen antibakteri yang potensial, termasuk tanaman senggugu (Rotheca serrata (L.) Steane \& Mabb.). Penelitian ini bertujuan mengetahui aktivitas antibakteri dan kandungan fitokimia dari ekstrak dan fraksi senggugu terhadap bakteri Pseudomonas aeruginosa ATCC 27853. Ekstraksi dilakukan dengan menggunakan metanol. Fraksinasi bertingkat dilakukan untuk mendapatkan fraksi n-heksana, diklorometana, etil asetat, dan residu. Skrining fitokimia dilakukan untuk menentukan alkaloid, terpenoid/steroid, flavonoid, dan polifenol menggunakan metode KLT. Uji aktivitas antibakteri dilakukan menggunakan metode mikrodilusi untuk menentukan nilai $\mathrm{IC}_{50}$. Ekstrak mengandung terpenoid/steroid, flavonoid, polifenol. Fraksi n-heksana dan diklorometana mengandung terpenoid/steroid. Fraksi etil asetat dan residu mengandung flavonoid dan polifenol. Nilai $\mathrm{IC}_{50}$ terendah dicapai oleh fraksi n-heksana sebesar $176,919 \pm 6,303 \mu \mathrm{g} / \mathrm{mL}$. Ekstrak dan fraksi senggugu memiliki aktivitas antibakteri yang moderat.
\end{abstract}

Kata kunci: Senggugu; Antibakteri; Skrining fitokimia; Pseudomonas aeruginosa

\begin{abstract}
Phytochemical Screening and Antibacterial Activity of Senggugu (Rotheca serrata (L.) Steane \& Mabb.) Crude Extract and Fractions against Pseudomonas aeruginosa. Irrationality of uncontrolled antibiotic therapy is reported to cause antibiotic resistance bacteria, thus enhancing the discovery of an alternative antibacterial agent. The diversity exploration of Indonesian medicinal plants is still promising to reveal a potential antibacterial agent, including senggugu (Rotheca serrata (L.) Steane \& Mabb.). This study aimed to determine the antibacterial activity and phytochemical content of the crude extract and its fractions of senggugu against Pseudomonas aeruginosa ATCC 27853. Extraction was done using methanol. Subsequent fractionation was carried out to obtain n-hexane, dichloromethane, ethyl acetate, and residue fractions. Phytochemical screening was performed for alkaloids, terpenoids/steroids, flavonoids, and polyphenols using TLC method. Broth microdilution method was carried out to obtain $\mathrm{IC}_{50}$ value. The crude extract contained terpenoids/steroids, flavonoids, and polyphenols. The n-hexane and dichloromethane fractions contained terpenoids/steroids. Ethyl acetate and residue fractions contained flavonoids and polyphenols.
\end{abstract}


The lowest $\mathrm{IC}_{50}$ value was revealed by $\mathrm{n}$-hexane fraction of $176.919 \pm 6.303 \mu \mathrm{g} / \mathrm{mL}$. The crude extract and its fractions of senggugu have moderate antibacterial activity.

Keywords: Senggugu; Antibacterial; Phytochemical Screening; Pseudomonas aeruginosa

\section{Pendahuluan}

Angka morbiditas dan mortalitas manusia di dunia yang disebabkan oleh infeksi bakteri cukup tinggi (Yanling et al., 2013). Menurut WHO (2016), penyakit infeksi bakteri dapat membunuh hampir 9 juta orang di seluruh dunia tiap tahunnya. Upaya peningkatan harapan hidup pasien penyakit infeksi bakteri selama 5 dekade terakhir dilakukan dengan terapi antibiotik (Sarmah et al., 2006), namun irasionalitas terapi antibiotik yang tidak terkontrol menyebabkan bakteri resisten antibiotik (Yezli \& Li, 2012).

Bakteri Pseudomonas aeruginosa merupakan patogen oportunistik pada infeksi nosokomial (Azizah \& Antarti, 2019). Pseudomonas aeruginosa dilaporkan resisten terhadap antibiotik golongan $\beta$-laktam, tetrasiklin, dan sulfonamida (Rukmono \& Zuraida, 2013). Data epidemiologis resistensi bakteri Pseudomonas aeruginosa di Indonesia diperkirakan terus meningkat, namun sangat sedikit data yang tercatat secara klinis (Parathon et al., 2017). Resistensi bakteri Pseudomonas aeruginosa memicu eksplorasi agen antibakteri baru.

Keanekaragaman tanaman endemik Indonesia yang mencapai 40.000 spesies (Nugraha et al., 2019), menjadikan tanaman sebagai kandidat agen antibakteri baru, salah satunya senggugu (Rotheca serrata (L.) Steane \& Mabb.). Senggugu merupakan tanaman perdu asli India Timur yang menyebar ke Asia Tenggara, termasuk Indonesia (Patel et al., 2014). Pada penelitian sebelumnya, ekstrak aseton daun senggugu dilaporkan memiliki aktivitas antibakteri dengan MIC 2 mg/mL terhadap Eschericia coli, Bacillus subtilis, dan Staphylococcus aureus (Indriani, 2007). Hingga kini, penelitian aktivitas antibakteri ekstrak metanol dan fraksi senggugu belum pernah dilakukan terhadap Pseudomonas aeruginosa, sehingga penelitian ini menunjang potensi pengembangan antibakteri baru terhadap Pseudomonas aeruginosa. Penelitian ini bertujuan mengetahui aktivitas antibakteri dan kandungan fitokimia dari ekstrak dan fraksi senggugu terhadap bakteri Pseudomonas aeruginosa ATCC 27853.

\section{Bahan dan Metode}

\subsection{Bahan}

Simplisia daun senggugu yang diperoleh dari Materia Media Kota Batu, aqua demineralata, metanol, n-heksana, diklorometana, etil asetat, butanol, asam asetat glasial, kloroform, kalium hidroksida, besi (III) klorida, dragendorf, asam sulfat, anisaldehid-asam sulfat, amonium hidroksida, plat silica gel $\mathrm{F}_{254}$, Mueller Hinton Broth (Merck), Mueller Hinton 
Agar (Merck), kalsium klorida (Merck), magnesium klorida (Merck), Pseudomonas aeruginosa ATCC 27853, dimetilsulfoksida, dan gentamisin.

\subsection{Metode}

\subsubsection{Preparasi sampel}

Serbuk simplisia daun senggugu dimaserasi menggunakan metanol dengan perbandingan 1:5 yang disertai pengadukan dengan magnetic stirrer selama 24 jam. Maserat dikeringkan menggunakan oven pada $40^{\circ} \mathrm{C}$ hingga didapatkan ekstrak kering. Ekstrak kering selanjutnya dilarutkan dalam air:metanol (9:1) dan difraksinasi bertingkat dengan perbandingan 1:1 sehingga didapatkan fraksi n-heksana, diklorometana, etil asetat, dan residu.

\subsubsection{Skrining fitokimia}

Sampel ekstrak atau fraksi senggugu sebanyak $20 \mathrm{mg}$ dilarutkan dalam $2 \mathrm{~mL}$ metanol, kemudian dilakukan skrining fitokimia dengan prosedur sebagai berikut:

a. Alkaloid

Sampel ditambahkan $\mathrm{HCl}$ 2N sebanyak 1,7 mL dan dipanaskan sekitar 3 menit. Sebanyak 0,1 gram $\mathrm{NaCl}$ ditambahkan, disaring, kemudian filtratnya ditotolkan pada lempeng KLT dan dieluasi dengan campuran etil asetat:metanol:air (9:2:2). Hasil positif alkaloid apabila terdapat noda berwarna jingga setelah disemprot dragendorf.

b. Flavonoid

Sampel ditotolkan langsung pada lempeng KLT dan dieluasi dengan lapisan bagian atas dari campuran butanol:asam asetat glasial:air (4:1:5). Hasil positif flavonoid apabila terdapat noda berwarna kuning setelah dipaparkan pada uap ammonia.

c. Polifenol

Sampel ditotolkan langsung pada lempeng KLT dan dieluasi dengan campuran kloroform:etil asetat (1:9). Hasil positif polifenol apabila terdapat noda berwarna hitam setelah disemprot $\mathrm{FeCl}_{3}$.

d. Terpenoid atau steroid

Sampel ditotolkan pada lempeng KLT dan dieluasi dengan campuran n-heksana:etil asetat (4:1) sebagai fase gerak. Hasil positif terpenoid atau steroid apabila terdapat noda berwarna ungu atau merah ungu setelah disemprot anisaldehida-asam sulfat dan dipanaskan pada suhu $105^{\circ} \mathrm{C}$.

\subsubsection{Uji aktivitas antibakteri}

Prosedur pada uji aktivitas antibakteri pada penelitian ini mengacu pada protokol standar yaitu CLSI M07-A9 dengan tahapan-tahapan sebagai berikut: 
a. Pembuatan media

Media MHA dibuat dengan menimbang sebanyak 1,6 gram MHA dilarutkan dalam 80 $\mathrm{mL}$ akuades demineralisasi. Media CAMHB dibuat dengan menimbang sebanyak 9,45 gram MHB dilarutkan dalam $150 \mathrm{~mL}$ akuades demineralisasi dan ditambahkan $\mathrm{MgCl}_{2}$ dan $\mathrm{CaCl}_{2}$ hingga didapatkan kandungan $\mathrm{Mg}^{2+}$ sebesar 11,25 mg/L dan $\mathrm{Ca}^{2+}$ sebesar 22,5 mg/L.

b. Pembuatan larutan uji

DMSO 100\% diencerkan dengan media CAMHB hingga didapatkan DMSO 1\% sebagai kontrol negatif. Gentamisin $40 \mathrm{mg} / \mathrm{mL}$ diencerkan dengan media CAMHB hingga didapatkan seri konsentrasi 4, 2, 1, dan $0,5 \mu \mathrm{g} / \mathrm{mL}$ sebagai kontrol positif. Larutan induk ekstrak dan fraksi senggugu $2048 \mu \mathrm{g} / \mathrm{mL}$ diencerkan dengan media CAMHB hingga didapatkan seri konsentrasi $1024,512,256,128$, dan $64 \mu \mathrm{g} / \mathrm{mL}$.

c. Peremajaan dan pembuatan suspensi bakteri

Biakan murni Pseudomonas aeruginosa diremajakan menggunakan media MHA dan diinkubasi pada $37^{\circ} \mathrm{C}$ selama 24 jam. Sebanyak 2-3 koloni Pseudomonas aeruginosa hasil peremajaan disuspensikan (Mc Farland 0,5) dalam media CAMHB.

d. Uji aktivitas antibakteri mikrodilusi

Sebanyak $50 \mu \mathrm{L}$ suspensi bakteri ditambahkan dengan $50 \mu \mathrm{L}$ DMSO 1\%, $50 \mu \mathrm{L}$ gentamisin, atau $50 \mu \mathrm{L}$ larutan ekstrak dan fraksi senggugu di dalam microplate-96-well. Iinkubasi dilakukan pada suhu $37^{\circ} \mathrm{C}$ selama 20 jam, kemudian diukur absorbansinya pada 625 nm. Data nilai absorbansi dimasukkan ke dalam rumus untuk mencari \% penghambatan (Ardani et al., 2010). Nilai $\mathrm{IC}_{50}$ (penghambatan 50\%) didapatkan melalui analisis probit menggunakan rumus persamaan 1 .

$$
\% \text { penghambatan }=\left(1-\frac{(\text { Abs.R }- \text { Abs.S })}{(\text { Abs.P }-A b s . Q)}\right) \times 100 \%
$$

Persamaan 1. Persamaan pengukuran persentase pengıaııvataı pengujian aktivitas antibakteri. Keterangan: absorbansi (Abs), kontrol negatif (DMSO 1\% atau media + suspensi bakteri) (P), kontrol media (DMSO 1\% atau media) (Q), uji (ekstrak/fraksi/gentamisin + suspensi bakteri) $(\mathrm{R}), \quad$ kontrol uji (ekstrak/fraksi/gentamisin + media) $(\mathrm{S})$

\section{Hasil dan Pembahasan}

Skrining fitokimia yang dilakukan secara KLT pada ekstrak metanol dan fraksi senggugu meliputi uji alkaloid, terpenoid atau steroid, flavonoid, dan polifenol. Pada penelitian ini, skrining fitokimia saponin dan antrakuinon tidak dilakukan karena kedua golongan senyawa tersebut tidak terdapat dalam genus Rotheca (Patel et al., 2014) dan umumnya juga kurang berperan sebagai antibakteri dalam beberapa famili tanaman, termasuk famili Lamiaceae 
(Compean \& Ynalvez, 2014). Hasil skrining fitokimia ekstrak metanol daun senggugu dan fraksi daun senggugu dapat dilihat pada Tabel 1dan Tabel 2.

Tabel 1. Hasil skrining fitokimia secara KLT pada ekstrak metanol daun senggugu (Rotheca serrata (L.) Steane \& Mabb.). Keterangan: ada (+) dan tidak ada (-).

\begin{tabular}{lcl}
\hline \multicolumn{1}{c}{ Golongan Senyawa } & Hasil & \multicolumn{1}{c}{ Keterangan } \\
\hline Alkaloid & - & Tidak timbul noda jingga \\
Steroid/terpenoid bebas & + & Timbul noda warna ungu atau merah ungu \\
Flavonoid & + & Timbul warna kuning \\
Polifenol & + & Timbul warna hitam \\
\hline
\end{tabular}

Hasil skrining fitokimia menunjukkan kesesuaian dengan Kumar (2013), yang menyatakan bahwa golongan senyawa metabolit sekunder yang ditemukan pada pada genus Rotheca berupa fenolik, flavonoid, terpenoid, dan steroid. Pada penelitian ini, kandungan alkaloid tidak ditemukan pada ekstrak metanol daun senggugu. Mengacu pada penelitian sebelumnya oleh Mohamed et al. (2012), kandungan alkaloid juga tidak ditemukan pada ekstrak metanol daun senggugu. Ekstrak metanol daun senggugu dimungkinkan memang tidak mengandung alkaloid atau dalam persentase yang sangat sedikit.

Tabel 2. Hasil skrining fitokimia secara KLT pada fraksi daun senggugu (Rotheca serrata (L.) Steane \& Mabb.). Keterangan: ada (+) dan tidak ada (-).

\begin{tabular}{lccc}
\hline \multirow{2}{*}{ Fraksi } & \multicolumn{3}{c}{ Golongan Senyawa } \\
\cline { 2 - 4 } & \multicolumn{4}{c}{ Steroid/terpenoid bebas } & Flavonoid & Polifenol \\
\hline$n$-heksana & + & - & - \\
Diklorometana & + & - & - \\
Etil asetat & - & + & + \\
Residu & - & + & + \\
\hline
\end{tabular}

Perbedaan polaritas pelarut fraksinasi menyebabkan distribusi golongan senyawa pada masing-masing fraksi juga berbeda (Nasrudin et al., 2017). Pelarut n-heksana bersifat non polar yang mampu menarik senyawa seperti steroid, terpenoid, dan aglikon (Widyawati et al., 2014), sehingga pada fraksi n-heksana senggugu ditemukan adanya kandungan terpenoid dan steroid. Pelarut diklorometana dan etil asetat bersifat semipolar yang mampu menarik senyawa alkaloid, aglikon, glikosida, flavonoid, polifenol (Iloki-Assanga et al., 2015), serta diklorometana mampu menarik sedikit steroid dan terpenoid (Thavamoney et al., 2018). Fraksinasi menggunakan pelarut diklorometana dilakukan terlebih dahulu daripada etil asetat, sehingga dimungkinkan sedikit kandungan steroid dan terpenoid dari residu fraksi n-heksana dapat terlarut pada fraksi dikrolometana, sedangkan yang dominan terlarut dalam fraksi etil asetat meliputi glikosida flavonoid dan polifenol. Residu dengan pelarut air yang polar mampu menarik metabolit sekunder seperti fenolik, flavonoid, tanin, alkaloid, dan glikosida (Felhi et 
al., 2017), sehingga pada residu senggugu ditemukan adanya kandungan polifenol dan flavonoid.

Prosedur uji antibakteri dengan metode mikrodilusi pada penelitian dapat dikatakan berjalan dengan baik karena nilai MIC (penghambatan $>80 \%$ ) hasil pengujian gentamisin sebagai kontrol positif sesuai dengan persyaratan MIC yang ditetapkan oleh CLSI yaitu pada konsentrasi 0,5-2 $\mu \mathrm{g} / \mathrm{mL}$ (CLSI, 2015). Aktivitas antibakteri DMSO 1\% sebagai kontrol negatif juga terhitung sebesar $-4,133 \pm 5,524 \%$, sehingga dapat dikatakan tidak mempengaruhi aktivitas antibakteri ekstrak dan fraksi daun senggugu. Nilai $\mathrm{IC}_{50}$ dari ekstrak dan fraksi daun senggugu disajikan pada Tabel 3.

Tabel 3. Nilai $\mathrm{IC}_{50}$ dari sampel uji senggugu terhadap Pseudomonas aeruginosa. Huruf yang sama ( $a, b, c, d)$ menunjukkan perbedaan yang tidak signifikan $(\mathrm{p}>0,05)$ antar kelompok uji.

\begin{tabular}{|c|c|c|}
\hline Sampel Uji & $\begin{array}{c}\mathrm{IC}_{50} \pm \mathrm{SD}(\mu \mathrm{g} / \mathrm{mL}) \\
(\mathrm{n}=3)\end{array}$ & $\begin{array}{l}\text { CV } \\
(\%) \\
\end{array}$ \\
\hline Ekstrak metanol & $380,462 \pm 17,014^{\mathrm{a}}$ & 4,472 \\
\hline Fraksi n-heksana & $176,919 \pm 6,303^{\mathrm{b}}$ & 3,563 \\
\hline Fraksi diklorometana & $343,767 \pm 12,399^{a}$ & 3,607 \\
\hline Fraksi etil asetat & $547,255 \pm 12,006^{\mathrm{c}}$ & 2,194 \\
\hline Residu & $924,943 \pm 27,393^{\mathrm{d}}$ & 2,962 \\
\hline
\end{tabular}

Perbedaan aktivitas penghambatan pertumbuhan Pseudomonas aeruginosa dapat disebabkan oleh perbedaan kandungan dan konsentrasi golongan senyawa di dalamnya. Nilai $\mathrm{IC}_{50}$ yang semakin kecil menunjukkan bahwa kemampuan aktivitas antibakteri semakin besar. Nilai $\mathrm{IC}_{50}$ terendah ditunjukkan oleh fraksi n-heksana daun sengggu, namun masih kurang poten karena standar nilai $\mathrm{IC}_{50}$ antiinfeksi yang baik untuk sampel yang mengandung lebih dari satu senyawa yaitu $<100 \mu \mathrm{g} / \mathrm{mL}$ (Cos et al., 2006). Keterulangan hasil uji dapat diterima karena nilai CV tidak melebihi persyaratan pengujian berbasis sel yaitu nilai CV $<30 \%$ (The Commision of The European Communities, 2005).

Aktivitas antibakteri yang paling baik dicapai oleh fraksi n-heksana dengan kandungan steroid dan terpenoid. Terpenoid dan steroid merupakan golongan senyawa yang mayoritas berperan utama sebagai antibakteri pada famili Lamiaceae (Compean \& Ynalvez, 2014). Terpenoid atau steroid secara umum memiliki mekanisme kerja dengan menyebabkan kebocoran dari liposom dan mampu mengganggu integrasi membran lipid terutama pada bakteri gram negatif yang susunan dinding selnya relatif nonpolar (Wolska et al., 2010). Terpenoid dan steroid yang telah diisolasi dari daun senggugu masing-masing disajikan lebih lanjut pada Gambar 1 dan Gambar 2. 


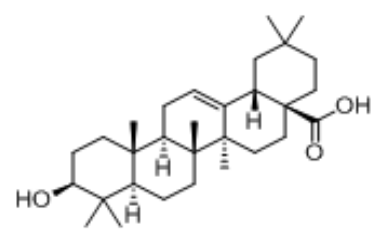

1

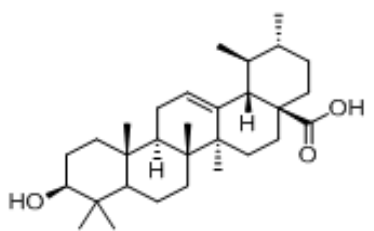

4

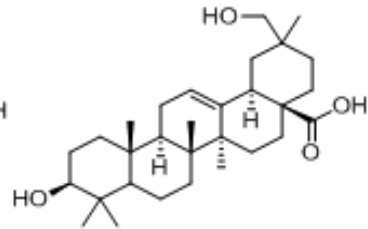

2

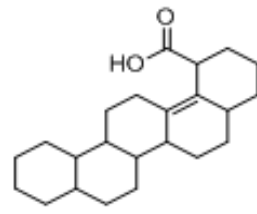

5

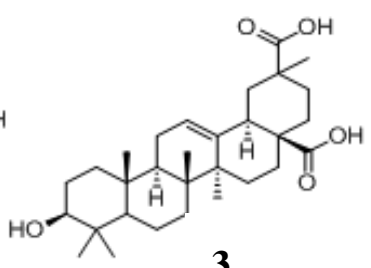

3

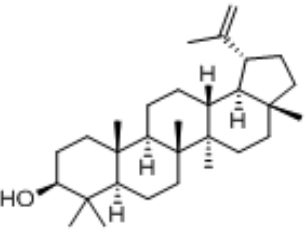

6

Gambar 1. Struktur kimia terpenoid senggugu asam oleanolat 1, asam kueretaroat 2, asam seratagenat 3, asam ursolat 4, asam ikosahidropisenat 5, dan lupeol 6 (Patel et al., 2014).

Asam oleanolat dan asam ursolat telah diteliti memiliki aktivitas antibakteri terhadap $P$. aeruginosa dengan nilai MIC yaitu $256 \mu \mathrm{g} / \mathrm{mL}$ (Fontanay et al., 2008). Asam seratagenat telah diteliti memiliki aktivitas antibakteri terhadap Bacillus subtilis, Staphylococcus aureus, dan Escherecia coli dengan nilai MIC $>250 \mu \mathrm{g} / \mathrm{mL}$ (Sultana \& Afolayan, 2007). Kandungan terpenoid atau steroid lainnya yang belum pernah diteliti aktivitas antibakterinya, serta kandungan asam oleanolat, asam ursolat, maupun asam seratagenat daun senggugu dimungkinkan berkontribusi dalam memberikan aktivitas antibakteri dari fraksi n-heksana.

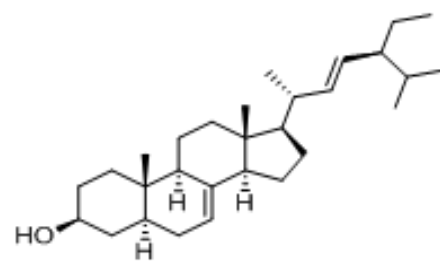

7

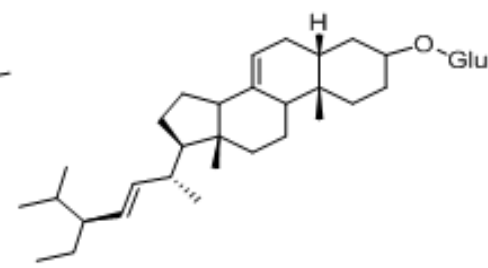

8

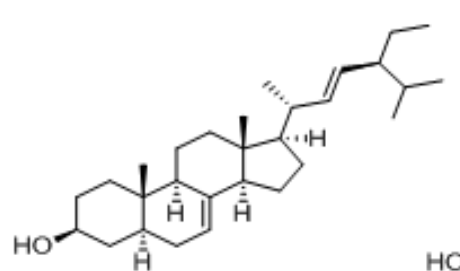

9

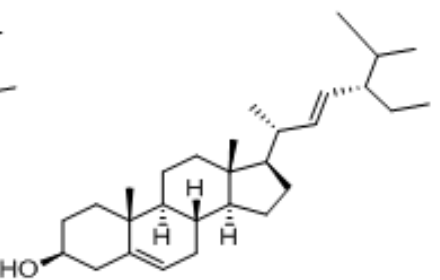

10

Gambar 2. Struktur kimia steroid senggugu spinasterol 7, spinasteril- $\beta$-D-glukopiranosida 8 , $\alpha$-spinasterol 9, stigmasterol 10 (Patel et al., 2014).

Aktivitas antibakteri berdasarkan nilai $\mathrm{IC}_{50}$ dari terendah hingga tertinggi selanjutnya dicapai oleh fraksi diklorometana. Pelarut diklorometana mampu menarik golongan senyawa terpenoid dan steroid (Thavamoney et al., 2018). Hal tersebut memungkinkan fraksi diklorometana menarik golongan senyawa terpenoid dan steroid yang bersifat antibakteri dari residu fraksi n-heksana, namun dengan konsentrasi yang lebih rendah dari fraksi n-heksana. 
<smiles>Oc1cc(O)c2c(c1)OC(c1ccc(O)c(O)c1)C(O)C2</smiles>

1<smiles>O=c1cc(-c2ccc(O)cc2)oc2cc(O)cc(O)c12</smiles>

4

14<smiles>O=C(O)C1OC(Oc2cc(O)c3c(=O)cc(-c4ccc(O)c(O)c4)oc3c2)[C@H](O)[C@H](O)[C@@H]1O</smiles>

2<smiles>O=c1cc(-c2ccc(O)c(O)c2)oc2cc(O)c(O)c(O)c12</smiles>

15<smiles>O=c1cc(-c2ccc(O)cc2)oc2cc(O)c(O)c(O)c12</smiles>

3<smiles>O=c1cc(-c2ccccc2)oc2cc(O)c(O)c(O)c12</smiles>

16

Gambar 3. Strukıur кımia flavonoid senggugu katekin 11, luteolin-7-O- $\beta$-D-glukonoida 12, 6hidroksiluteolin 15, apigenin 14, 5,6,7,4'-tetrahidroksiflavon 13, dan baikalein 16 (Patel dkk., 2014).

Fraksi etil asetat dan residu daun senggugu menunjukkan aktivitas antibakteri yang rendah dengan kandungan flavonoid dan polifenol. Flavonoid dan polifenol pada senggugu umumnya merupakan glikosida yang dapat larut air (Mohamed et al., 2012). Secara umum, flavonoid memiliki mekanisme kerja melalui pembentukan kompleks dengan protein ekstraseluler pada dinding sel bakteri (Mujeeb et al., 2014), sedangkan polifenol (hydrolysable tannins) memiliki mekanisme kerja melalui pembentukan kompleks dengan enzim hidrolitik sehingga mengganggu membran sel (Januarti et al., 2019), interaksi non spesifik dengan karbohidrat, dan interaksi lain yang menonaktifkan adhesin (Karou et al., 2005). Flavonoid dan polifenol memang bukan golongan senyawa antibakteri utama famili Lamiaceae, namun beberapa diantaranya berkontribusi sebagai antibakteri (Compean \& Ynalvez, 2014; Nugraha, 2015). Berdasarkan hal tersebut, flavonoid dan polifenol pada fraksi etil asetat dan residu daun senggugu dimungkinkan memang bukan senyawa antibakteri atau senyawa antibakteri dengan aktivitas yang rendah. Flavonoid dan polifenol yang pernah diisolasi pada daun senggugu masing-masing disajikan lebih lanjut pada Gambar 3 dan Gambar 4.

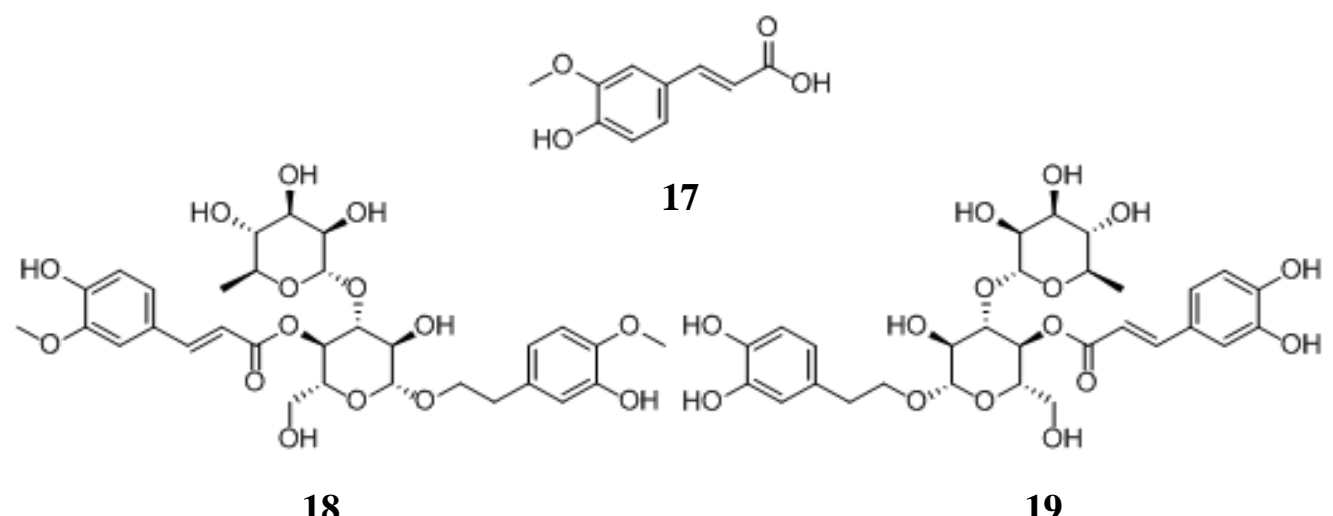

Gambar 4. Struktur kimia polifenol senggugu asam ferulat 17, martinosida 18, dan verbakosida 19 (Patel dkk., 2014). 


\section{Kesimpulan}

Aktivitas antibakteri yang paling baik dicapai oleh fraksi $n$-heksana dengan nilai $\mathrm{IC}_{50}$ terkecil yaitu 176,919 $\pm 6,303 \mu \mathrm{g} / \mathrm{mL}$ terhadap bakteri Pseudomonas aeruginosa ATCC 27853. Ekstrak metanol senggugu mengandung terpenoid/steroid, fenolik, dan flavonoid. Fraksi nheksana dan diklorometana mengandung terpenoid/steroid. Fraksi etil asetat dan residu mengandung fenolik dan flavonoid. Penelitian yang perlu dilakukan selanjutnya adalah isolasi senyawa yang bertanggung jawab terhadap aktivitas antimikroba.

\section{Ucapan Terimakasih}

Penulis mengucapkan terimakasih kepada Universitas Jember atas dukungan fasilitas penelitian.

\section{Deklarasi Konflik Kepentingan}

Semua penulis menyatakan tidak ada konflik kepentingan terhadap naskah ini.

\section{Daftar Pustaka}

Ardani, M., Pratiwi, S. U. T., \& Hertiani, T. (2010). Efek campuran minyak atsiri daun cengkeh dan kulit batang kayu manis sebagai antiplak gigi. Majalah Farmasi Indonesia, 21(3), 191-201.

Azizah, R., \& Antarti, A. N. (2019). Uji aktivitas antibakteri ekstrak dan getah pelepah serta bonggol pisang kepok kuning (Musa paradisiaca Linn.) terhadap bakteri Pseudomonas aeruginosa dan Klebsiella pneumoniae dengan metode difusi agar. JPSCR : Journal of Pharmaceutical Science and Clinical Research, 4(1), 29.

CLSI. (2015). M07-A10 Methods for Dilution Antimicrobial Susceptibility Tests for Bacteria That Grow Aerobically; Approved Standard-Tenth Edition.

Compean, K. L., \& Ynalvez, R. A. (2014). Antimicrobial activity of plant secondary metabolites: A review. Research Journal of Medicinal Plant, 8(5), 204-213.

Cos, P., A. J. Vlietinck, D. Vanden Berghe, dan L. Maes. (2006). Anti-infective potential of natural products: How to develop a stronger in vitro "proof of concept". Journal of Ethnopharmacology. 106(3):290-302.

Felhi, S., Daoud, A., Hajlaoui, H., Mnafgui, K., Gharsallah, N., \& Kadri, A. (2017). Solvent extraction effects on phytochemical constituents profiles, antioxidant and antimicrobial activities and functional group analysis of Ecballium elaterium seeds and peels fruits. Food Science and Technology, 37(3), 483-492.

Fontanay, S., Grare, M., Mayer, J., Finance, C., \& Duval, R. E. (2008). Ursolic, oleanolic and betulinic acids: Antibacterial spectra and selectivity indexes. Journal of Ethnopharmacology, 120(2), 272-276.

Iloki-Assanga, S. B., Lewis-Luján, L. M., Lara-Espinoza, C. L., Gil-Salido, A. A., FernandezAngulo, D., Rubio-Pino, J. L., \& Haines, D. D. (2015). Solvent effects on phytochemical constituent profiles and antioxidant activities, using four different extraction formulations for analysis of Bucida buceras L. and Phoradendron californicum. Biomed Central Research Notes, 8(1), 1-14.

Indriani, N. (2007). Aktivitas Antibakteri Daun Senggugu (Clerodendron serratum [L.] Spr.). Bogor Agricultural University.

Januarti, I. B., Wijayanti, R., Wahyuningsih, S., \& Nisa, Z. (2019). Potensi ekstrak terpurifikasi daun sirih merah (Piper crocatum Ruiz \& Pav) sebagai antioksidan dan antibakteri. JPSCR : Journal of Pharmaceutical Science and Clinical Research, 4(2), 60. 
Karou, D., M. H. Dicko, J. Simpore, dan A. S. Traore. 2005. Antioxidant and antibacterial activities of polyphenols from ethnomedicinal plants of Burkina faso. African Journal of Biotechnology. 4(8):823-828.

Kumar, P. (2013). Phytochemical and pharmacological profiles of Clerodendrum serratum Linn. (bharngi): A review. International Journal of Research in Ayurveda and Pharmacy, $4(2), 276-278$.

Mohamed, A. J., Mohamed, E. A. H., Aisha, A. F., Ameer, O. Z., Ismail, Z., Ismail, N., Yam, M. F. (2012). Antioxidant, antiangiogenic and vasorelaxant activities of methanolic extract of Clerodendrum serratum (Spreng.) leaves. Journal of Medicinal Plants Research, 6(3), 348-360.

Mujeeb, F., P. Bajpai, dan N. Pathak. 2014. Phytochemical evaluation, antimicrobial activity, and determination of bioactive components from leaves of Aegle marmelos. Biomed Research International. 1-11.

Nasrudin, Wahyono, Mustofa, \& Asmah, R. (2017). Hepatoprotective activity of ethyl acetate fraction of Senggugu's root bark (Clerodendrum serratum L. Moon ) on rats induced by carbon tetrachloride. Indonesian Journal of Pharmacy, 28(1), 10-18.

Nugraha, A. S., Pratoko, D. K., Damayanti, Y. D., Lestari, N. D., Laksono, T. A., Addy, H. S., Untari, L. F., Kusumawardani, B., \& Wangchuk, P. (2019). Antibacterial and anticancer activities of nine lichens of Indonesian Java island. Journal of Biologically Active Products from Nature, 9(1), 39-46.

Nugraha, A. S. (2015). Natural product studies on tropical and polar plants. $\mathrm{PhD}$ Thesis, University of Wollongong, Australia.

Parathon, H., Kuntaman, K., Widiastoety, T. H., Muliawan, B. T., Karuniawati, A., Qibtiyah, M., Vong, S. (2017). Progress towards antimicrobial resistance containment and control in Indonesia. British Medical Journal, 358, 3808.

Patel, J. J., Sanjeev, R. A., \& Acharya, N. S. (2014). Clerodendrum serratum (L.) Moon. - A review on traditional uses, phytochemistry, and pharmacological activities. Journal of Ethnopharmacology, 154(2), 268-285.

Rukmono, P., \& Zuraida, R. (2013). Uji kepekaan antibiotik terhadap pseudomonas aeruginosa penyebab sepsis neonatorum. Sari Pediatri, 14(5), 332-336.

Sarmah, A. K., Meyer, M. T., \& Boxall, A. B. A. (2006). A global perspective on the use, sales, exposure pathways, occurrence, fate and effects of veterinary antibiotics (VAs) in the environment. Chemosphere, 65(5), 725-759.

Sultana, N., \& Afolayan, A. J. (2007). A novel daucosterol derivative and antibacterial activity of compounds from Arctotis arctotoides. Natural Product Research, 21(10), 889-896.

Thavamoney, N., Sivanadian, L., Tee, L. H., Khoo, H. E., Prasad, K. N., \& Kong, K. W. (2018). Extraction and recovery of phytochemical components and antioxidative properties in fruit parts of Dacryodes rostrata influenced by different solvents. Journal of Food Science and Technology, 55(7), 2523-2532.

The Commision of The European Communities. 2005. Requirements for the Determination of Levels of Dioxins and Dioxin-Like PCBs in Feedingstuffs Rules. Commision Regulation: Subsidiary Legislation 473.54.

WHO. 2016. The Top 10 Causes of Death. Retrieved from https://www.who.int/newsroom/fact-sheets/detail/the-top-10-causes-of-death.

Widyawati, P. S., Dwi, T., Budianta, W., \& Kusuma, F. A. (2014). Difference of solvent polarity to phytochemical content and antioxidant activity of Pluchea indicia less leaves extracts. International Journal of Pharmacognosy and Phytochemical Research, 6(4), $850-855$.

Wolska, K. I., Grudniak, A. M., Fiecek, B., Kraczkiewicz-Dowjat, A., \& Kurek, A. (2010). Antibacterial activity of oleanolic and ursolic acids and their derivatives. Central European Journal of Biology, 5(5), 543-553. 
Yanling, J., Xin, L., \& Zhiyu, L. (2013). The Antibacterial Drug Discovery. In Drug Discovery. Yezli, S., \& Li, H. (2012). Antibiotic resistance amongst healthcare-associated pathogens in China. International Journal of Antimicrobial Agents, 40(5), 389-397.

\section{(c) (1) ()}

BY SA C 2020 by the authors. Submitted for possible open access publication under the terms and conditions of the Creative Commons Attribution-ShareAlike 4.0 International (CC BY-SA 4.0) license (https://creativecommons.org/licenses/by-sa/4.0/). 